International Journal of Linguistics, Literature and Culture
Available online at https://sloap.org/journals/index.php/ijllc/
Vol. 4, No. 6, November 2018, pages: $1 \sim 6$
ISSN: $2455-8028$
https://sloap.org/journals/index.php/ijllc/article/view/327

\title{
The Image of Super Woman: A Portrayal of Woman in Bernard Shaw's Pygmalion and The Millionairess
}

\author{
P. Neethi Mohan ${ }^{\text {a }}$ \\ S.P. Suresh Kumar ${ }^{b}$
}

\section{Article history:}

Received: 20 June 2018

Accepted: 30 August 2018

Published: 8 October 2018

\section{Keywords:}

Empowerment;

Feminism,

Socialism,

Understanding;

Women images;

\begin{abstract}
Socialism and Feminism stand first in the list of factors that influenced Shaw in creating strong women characters that must have looked arrogant and brass to the Victorian audience who had assigned a gentile and soft gender role to women. Shaw not only has created assertive women characters but he has created men with an open mind to accept such a woman as part of their society. This creation of understanding and accommodating men has complemented Shaw's women characters and has lent the space for them to move freely and interact with utmost liberty. If Shaw had created men who had narrower views on gender equality and who are confirmative, Shaw would not have created a truly explosive gender dynamics that has become the hallmark of his plays. It is the influence of socialism and socialists which empowered Shaw to create and present such advanced characters and environment in his plays.
\end{abstract}

2455-8028 ${ }^{\circledR}$ Copyright 2018. The Author. This is an open-access article under the CC BY-SA license (https://creativecommons.org/licenses/by-sa/4.0/) All rights reserved.

\section{Author correspondence:}

P Neethi Mohan,

Assistant, PSG Polytechnic College, Coimbatore-641 004

Email address: neethimohan@gmail.com

\section{Introduction}

Innes, C. (Ed.). (1998), characterization is an important aspect that determines the extent to which a drama becomes realistic and lively. It may focus on rendering vivacious and individualistic characters that enliven the action on the stage, or it may stop at producing stereotypical representations of human beings and result in throwing, onto the stage, a bunch of manikins that perform a mockery of human dynamics. Therefore, dramatists contribute a considerable portion of their efforts in delineating their characters (Peters, 1998). Even though they are creative enough and make conscious attempts at creating original characters, most often, they are influenced by their

${ }^{\text {a }}$ PSG Polytechnic College, Coimbatore-641 004

${ }^{\mathrm{b}}$ PSG College of Technology, Coimbatore-India 
contemporaries that result in character creation that shares many common traits with the characters of other dramatists of the period.

Some dramatists succeed in breaking away from the convention and show their individualism. Shaw, G. B. (2002), (2015), Shaw is one such dramatist who broke away from his contemporaries and has carved a special place for himself in the British drama of the early twentieth century. As a follower of Ibsen and his school of naturalistic representation, Bernard Shaw has radically and vehemently moved away from his immediate predecessors in delineating characters for his plays. Unlike the Victorian dramatists, Shaw has created strong and dynamic personalities - women characters who are lively and assertive, men characters who are not super humans, but ordinary men who have strengths and weaknesses like all others. "My characters behave like human beings, instead of conforming to the romantic logic of the stage." (Shaw, Mrs. Warren's Profession)

Such a portrayal of realistic characters allows Shaw to demonstrate lively scenes that stage explosive interactions among the characters that act and react with strong emotions and gusto. Thus Shaw's plays become a perfect platform for exhibiting all human and gender interactions and dynamics in all their variety. He is able to accomplish this by creating strong women. Eliza Doolittle in Pygmalion and Epifania in The Millionairess are examples. This paper aims at analyzing how and why Shaw has created these two characters as part of his dramatic exploration (Nforbin, 2010).

\section{Materials and Methods}

Pygmalion, one of the masterpieces of Shaw was written in 1912. This play tells a rags-to-riches life. The play deals with the development of a relationship between a learned man and a street girl who sells flowers. It is a social critique on class divisions and its demarcations such as dialect. The Millionairess was written in 1934. This play is about how a rich woman outwits her father's will in order to get married.

Shaw's women are not the stereotypical Victorian women who play the expected gender roles that tradition has assigned to them. "An early and vigorous exponent of female/male equality, Shaw developed in his heroines that evolutionary principle of self-will and a total egoism to do their own wills rather than the collective will of society." (Nforbin 23) This is the reason why Shaw has delineated Mrs. Warren as a prostitute and her daughter Vivie as a career woman, Miss. Doolittle of Pygmalion as a self-reliant flower girl, and Lesbia of Getting Married as a spinster. Shaw has also created another set of explosive characters "such strong Shavian heroines as Ann Whitefield and Doña Ana in Man and Superman and Jennifer Dubedat in The Doctor's Dilemma. Shaw had conceived the tempestuous and problematic figure of Julia Craven in The Philanderer in much the same vein" (Marker 112) Miss. Doolittle is a strong-willed and determined woman who wishes to go up in life. Epifania is another woman protagonist who is daring and does not play the conventional role of a woman in the society. She describes herself as "I am an unusual woman. You will take the law from me and do exactly what I tell you to do. [...] I am a woman who must always want something and always get it. [...] And remember this. I have no sense of humor. I will not be laughed at." (Shaw, The Millionairess)

Miss Doolittle is a flower girl who is brought up in harsh conditions that are common to the lower class society of London. Unlike other women of her class, she is willing to work so she could go up in life. She is strong of will and bold in character. She is portrayed as a simpleton in her ways, but she holds herself as dignified as she perceives it. She is shrewd and hardworking. The entire play Pygmalion is a package of how Higgins and Miss Doolittle succeed in their endeavor. Shaw has portrayed Eliza as a courageous shrewd girl. In the opening scene, she does not miss an opportunity to get compensation for the spoiled flowers from Freddy's mother. She also sells flowers to Pickering. When Higgins is doubted for a cop, she speaks out for herself. Even then, she talks boldly expressing her views on herself and arguing her innocence: "I have a right to sell flowers if I keep off the curb. [Hysterically] I'm a respectable girl: so help me, [...] I'm a good girl, I am. [...]He's no right to take away my character. My character is the same to me as any lady's." (Shaw, Pygmalion 75) Eliza expresses her strong desire to go up in life and live a life that middle class and upper-class people live in the opening scene when she decides to take a taxi as she gets a lot of money from Higgins. She does not stop there; she goes to Higgins to learn to become a lady. This shows her determination.

Another strong woman character delineated by Shaw is Epifania of The Millionairess. Her introduction in the first act shows how domineering and bossy she is. She desires to make all the discussions and she is portrayed as an impulsive and restless woman which she herself reveals. The opening description of how she enters would suggest what sort of a character she is: "A tragic looking woman, athletically built and expensively dressed, storms into the 
room. He rises obsequiously." (Shaw, The Millionairess) She is described as thus: "Millionairess Epifania Ognisanti di Parerga Fitzfassenden is a judo expert who talks like a man and uses her fists on her passionless bridegroom" (Peters, 19). Epifania, with her aggressiveness both physically and mentally and her head-strongness, presents her as an aggressor and a bulldozer who demolishes anything and everything that comes across her in order to suit her. This would allow very conservative Victorian audiences to have apoplexy and heart attacks. Shaw has presented an aggressive woman and an aggressive man. Epifania and Alastair both are portrayed as boxers.

\section{Results and Discussions}

Eliza Doolittle is a bold woman at heart. Even though she expects a little kindness from Higgins, she expresses her determination in marrying a person who would love her and show kindness. Higgins talks about marriage as an ordinary event without understanding Eliza's heart. Even when he accepts her as a student, he talks of her marriage without any consideration for her feelings.

a) LIZA. Who'd marry me?

b) HIGGINS [suddenly resorting to the most thrillingly beautiful low tones in his best elocutionary style] By George, Eliza, the streets will be strewn with the bodies of men shooting themselves for your sake before I've done with you. (Shaw, Pygmalion)

c) The play The Millionairess revolves round one headstrong woman who just bulldozes any obstacle that appears in her path. When she treats marriage as her fancy, the consequences may encompass the entire gamut between the solemnity that is expressed in the greatness of true and divine love and the hilarity that is unveiled in childish romantic escapades. Both Eliza and Epifania are superwomen who overcome all obstacles to conquer what they wanted in their lives. They are superwomen because they succeed against all odds much like the conventional male superheroes. Shaw has presented these characters as models to be followed by other women of his period. He also highlights the point that men will be in a precarious position if they fail to acknowledge the praise of the woman folk.

d) Shaw's men and women do not play the conventional gender roles. Therefore the dynamics between both the sexes in his plays are also different. Women pursue men. Women play a dominant role in romance. Women are independent and assertive, so their actions appear to be contrary to conventions. "Female creations like Mrs. George in Getting Married (1908) and Hesione Hushaby in Heartbreak House (1917) are drenched in a seemingly supernatural sexuality. In Shaw's comic universe, women are more than equal to the ineffectual men around them." (Peters, 19) Men are intellectual, radical, and afraid of women. They play a hesitant and submissive role in romance. They often are portrayed as low in confidence and unsure of themselves in front of women. This timid man vs. bold woman often allows Shaw to orchestrate gender dynamics that gives him the space to propagate his advanced views on social reform. Nforbin describes Shaw's focus in playwriting to be "His socialist engagement and participation in the fn-de-Siecle search for "New women"; his role in redefining gender relations; his cordial dislike for love as culturally constructed in Victorian culture and fostered in 19th century comedies, and his fight against entrenched Victorian codes of conduct" (11).

e) Shaw created women who are strong and assertive because he wanted to create a society in with there would be no discrimination based on any and all inequalities. Furthermore, he pointed out the fact that biologically or otherwise, women are not in any way inferior to men. This is the reason why Shaw created women who exerted the same power as men do. Peters sums up this character of Shaw thus:

f) He remained a vegetarian, an anti-vivisectionist, an anti-vaccinationist, a wool-wearer, a eugenicist, a Fabian, and a feminist. Whatever Shaw's personal unhappiness, the extraordinarily productive life featured an upward trajectory, as he imposed his will and exercised his fancy on seemingly intractable materials, spinning out glorious comedies and enduring parables. Always his vision of the stage was at the apex of human endeavor, a place of beauty and spirituality. Believing that the fates of artists, homosexuals, and women are intertwined, insisting that all great art is didactic, he valiantly worked for a society unblemished by the inequalities of class or gender. (24)

Shaw was focused on creating strong women characters because he was influenced by socialism which was against women oppression. One of the major themes of Shaw's plays is a woman and her gender role. Shaw's preference and treatment of this theme is a clear mark of socialistic influence. The emotional, economic, and political state of women has most often been a central discussion point for socialists. Shaw's socialism and participation in women

Mohan, P. N., \& Kumar, S. S. (2018). The image of super woman: a portrayal of woman in Bernard Shaw's Pygmalion and the millionairess. International Journal of Linguistics, Literature and Culture, 4(6), 1-6. https://doi.org/10.21744/ijllc.v4n6.327 
liberation movements inspired him to a greater extent and he was reshaping comedy and melodrama in the light of the enlightened socialist discourses.

\section{Conclusion}

Shaw not only has created assertive women characters but he has created men with an open mind to accept such a woman as part of their society. This creation of understanding and accommodating men has complemented Shaw's women characters and has lent the space for them to move freely and interact with utmost liberty. If Shaw had created men who had narrower views on gender equality and who are confirmative, Shaw would not have created a truly explosive gender dynamics that has become the hallmark of his plays. It is the influence of socialism and socialists which empowered Shaw to create and present such advanced characters and environment in his plays. By creating strong woman characters, Shaw has planted the possibility of women appraisal and its subsequent women empowerment. He has given a glimpse of how relationships would be shaped in a society where there is gender equality. In this regard, he was a true prophet.

\section{Conflict of interest statement and funding sources}

The author(s) declared that (s)he/they have no competing interest. The study was financed by personal funding.

Statement of authorship

The author(s) have a responsibility for the conception and design of the study. The author(s) have approved the final article.

\section{Acknowledgments}

The author would like to thank the reviewer for their consideration to the further process of the peer review. The author as well as thanks to the editor for their support, valuable time, and advice. Last but not least, the author thanks all researcher for their contribution as the references to the present article. 


\section{References}

Innes, C. (Ed.). (1998). The Cambridge Companion to George Bernard Shaw. Cambridge University Press.

Nforbin, G. (2010). Bernard Shaw's reconfiguration of dramatic genres as force-fields in socio-cultural and new aesthetic criticism.

Peters, S. (1998). Bernard Shaw: the ascent of the superman. Yale University Press.

Shaw, G. B. (2002). George Bernard Shaw's Plays (Norton Critical Editions).

Shaw, G. B. (2015). Pygmalion. e-artnow sro.

Mohan, P. N., \& Kumar, S. S. (2018). The image of super woman: a portrayal of woman in Bernard Shaw's Pygmalion and the millionairess. International Journal of Linguistics, Literature and Culture, 4(6), 1-6. https://doi.org/10.21744/ijllc.v4n6.327 


\section{Biography of Authors}

\begin{tabular}{||l|l||}
\hline \hline & $\begin{array}{l}\text { Dr. Neethi Mohan is working at Assistant, PSG Polytechnic College, Coimbatore-India. } \\
\text { He has published articles on writing by women of Canadian, Indian and Sri Lankan } \\
\text { origin. He has published many research articles in various International and national } \\
\text { journals. He is also interested in Indian English novels and drama. } \\
\text { Email: neethimohan @ gmail.com }\end{array}$ \\
\hline \hline & $\begin{array}{l}\text { Mr.S.P. Suresh Kumar is employed as Associate Professor and Head of the Department } \\
\text { of English at PSG College of Technology, Coimbatore, Tamilnadu. His areas of } \\
\text { research include English and Indian Literature and Language Teaching, and he is on the } \\
\text { verge of submitting his doctoral thesis in Sri Aurobindo's poetry. He has published nine } \\
\text { research papers in International Journals so far and has presented many papers at } \\
\text { national and international conferences. } \\
\text { Email: suresh556@yahoo.com }\end{array}$ \\
\hline
\end{tabular}

